\title{
Pemanfaatan Sarana Macromedia Flash Dalam Pembelajaran Fiqih Di Kelas V Madrasah Ibtidaiyah Ainul Huda Juwet Ngronggot Nganjuk
}

\author{
Hilya Diana, ${ }^{1}$ A. Jauhar Fuad ${ }^{2}$ \\ ${ }^{1}$ Pascasarjana Institut Agama Islam Tribakti Kediri, 2 Institut Agama Islam Tribakti Kediri \\ 1hilyadiana87@gmail.com,2info.ajauharfuad@gmail.com
}

\begin{abstract}
Multimedia-based learning can certainly present learning material that is more interesting, not monotonous, and facilitates delivery. Students can learn certain subject matter independently with a computer equipped with multimedia programs. This research method is qualitative. As with the direction of qualitative research, the collected data is analyzed with the provision of intellectual weapons in the form of theory as presented in chapter II to obtain various interpretative descriptions in accordance with the rules of scientific research that are logical and rational. The results of this study are: (1) Utilization of macromedia flash as a medium for fiqh learning in Class V Ibtidaiyah Ainul Huda Juwet Nggruk Nganjuk based on the Alessi and Trollip model, which is broadly divided into several stages of use including determining needs and goals, gathering resources, study material, generate ideas, design learning, create material that supports, evaluates and reviews. (2) The effectiveness of using Macromedia Flash in fiqh learning in Class V Madrasah Ibtidaiyah Ainul Huda Juwet Ngronggot Nganjuk is effective enough to support learning in madrasas because it is supported by a very good display quality and easily accepted by students, presenting clear material and displaying concrete things. so students easily understand the material, user interactions and good program interactions so the teacher and students can be active in learning.
\end{abstract}

Keywords: Macromedia Flash, Figh Learning.

\begin{abstract}
Abstrak
Pembelajaran berbasis multimedia tentu dapat menyajikan materi pelajaran yang lebih menarik, tidak monoton, dan memudahkan penyampaian. Peserta didik dapat mempelajari materi pelajaran tertentu secara mandiri dengan komputer yang dilengkapi program multimedia. Metode penelitian ini adalah kualitatif. Sebagaimana arahan jenis penelitian kualitatif, maka data terkumpul dianalisis dengan bekal senjata intelektual berupa teori sebagaimana disampaikan sebagai perspektif untuk mendapatkan berbagai uraian interpretatif sesuai kaidah penelitian ilmiah yang logis dan rasional. Hasil penelitian ini adalah: (1) Pemanfaatan macromedia flash sebagai media pembelajaran fiqih di Kelas V Madrasah Ibtidaiyah Ainul Huda Juwet Ngronggot Nganjuk berdasarkan model Alessi dan Trollip yaitu secara garis besar dibagi menjadi beberapa tahapan pemakaian antara lain: menentukan
\end{abstract}


kebutuhan dan tujuan, mengumpulkan sumber, mempelajari materi, menghasilkan gagasan, mendesain pembelajaran, membuat materi yang mendukung, mengevaluasi dan meninjau kembali. (2) Efektifitas penggunaan Macromedia Flash pada pembelajaran fiqih di Kelas V Madrasah Ibtidaiyah Ainul Huda Juwet Ngronggot Nganjuk cukup efektif untuk menunjang pembelajaran di madrasah karena didukung kualitas tampilan yang sangat bagus dan mudah diterima oleh ssiwa, penyajian materi jelas dan menampilkan hal-hal yang kongkrit sehingga siswa mudah memahami materi, interaksi pengguna dan interaksi program yang baik sehingga guru dan siswa bisa aktif dalam belajar

Kata Kunci: Macromedia Flash, Pembelajaran Fiqih

\section{Pendahuluan}

Berdasarkan hasil pengamatan pendahulu di Madrasah Ibtidaiyah (MI) Ainul Huda Juwet Ngronggot Nganjuk, para guru sudah memanfaatkan media pembelajaran yang ada. Salah satunya adalah guru fiqih yang sudah mengembangkan media pembelajaran berbasis komputer dengan memakai program macromedia flash. Data awal pun menunjukkan adanya efektifitas peningkatan secara signifikan dalam penerapan program macromedia flash.

Tujuan Macromedia flash digunakan oleh guru di Madrasah Ibtidaiyah (MI) Ainul Huda Juwet Ngronggot Nganjuk untuk memberi gambaran secara kongkrit terhadap materi yang disampaikan. Dengan pemakaian media yang tepat siswa akan mudah meresap materi yang disampaikan karena dalam program macromedia flash terdapat animasi yang mudah ditangkap oleh para siswa. Hal ini untuk mempermudah siswa memahami materi yang disampaikan. Dan yang terpenting, mampu mendorong masyarakat untuk 
haji pada mata pelajaran fiqih menggunakan metode ceramah tentu masih menyisakan beberapa persoalan dalam aspek pemahaman siswa seperti bagaimanakah gambaran tentang thawaf, sai, wukuf, jumroh yang sudah tentu tidak bisa dijelaskan dengan satu metode itu saja. Adanya media yang mampu memaparkan haji dalam bentuk teks, gambar, suara, dan video (audiovisual) tentu sangat diperlukan.

Menyadari kenyataan seperti ini maka para tenaga pendidik di Madrasah Ibtidaiyah Ainul Huda Juwet Ngronggot Nganjuk berupaya untuk mencari dan mengembangan media pembelajaran yang dapat merangkul semua perbedaan yang dimiliki oleh anak didik. Sehingga guru fiqih di Madrasah Ibtidaiyah Ainul Huda Juwet Ngronggot Nganjuk menggunakan media pembelajaran Macromedia Flash dalam proses belajar mengajar.

Dengan melihat perkembangan pesat teknologi informasi dewasa ini maka Macromedia Flash tentu dapat menjadi tawaran pertama untuk memberikan solusi dari permasalahan di atas. Macromedia Flash merupakan gabungan konsep pembelajaran dengan teknologi audiovisual yang mampu menghasilkan fitur-fitur baru yang dapat dimanfaatkan dalam pendidikan. Pembelajaran berbasis multimedia tentu dapat menyajikan materi pelajaranyang lebih menarik, tidak monoton, dan memudahkan penyampaian. Peserta didik dapat mempelajari materi pelajaran tertentu secara mandiri dengan komputer yang dilengkapi program multimedia. ${ }^{1}$

Macromedia Flash adalah program untuk membuat animasi dan aplikasi web profesional. Bukan hanya itu, Macromedia Flash juga banyak digunakan untuk membuat game, animasi kartun, dan aplikasi multimedia interaktif seperti demo produk dan tutorial interaktif. ${ }^{2}$ Software keluaran Macromedia ini merupakan program untuk mendesain grafis animasi yang sangat populer dan banyak digunakan desainer grafis. Kelebihan flash terletak pada kemampuannya menghasilkan animasi gerak dan suara. Awal perkembangan flash banyak digunakan untuk animasi pada website, namun saat ini mulai banyak digunakan untuk media pembelajaran karena kelebihan-kelebihan yang dimiliki.

Berangkat dari konteks di atas maka peneliti merasa perlu untuk mengadakan penelitian di Madrasah Ibtidaiyah Ainul Huda Juwet Ngronggot Nganjuk dengan mengangkat judul tesis "Pemanfaatan Sarana Macromedia Flash dalam Pembelajaran Fiqih di Kelas V Madrasah Ibtidaiyah Ainul Huda Juwet Ngronggot Nganjuk". Guna memaksimalkan proses penelitian ini, peneliti merumuskan untuk menjawab permasalahan tentang, 
Pemanfaatan macromedia flash sebagai media pembelajaran fiqih di Kelas $\mathrm{V}$ Madrasah Ibtidaiyah Ainul Huda Juwet Ngronggot Nganjuk dan Efektifitas penggunaan Macromedia Flash pada pembelajaran fiqih di Kelas V Madrasah Ibtidaiyah Ainul Huda Juwet Ngronggot Nganjuk.

\section{Metode}

Penelitian ini menggunakan pendekatan kualitatif. Pendekatan kualitatif dipilih karena mampu mendeskripsikan sekaligus memahami makna yang mendasari tingkah laku partisipan, mendiskripsikan latar dan interaksi yang kompleks, eksplorasi untuk mengidentifikasi tipe-tipe informasi, dan mendeskripsikan feno-mena. ${ }^{3}$

Penelitian ini diharapkan dapat mendeskripsikan data secara menyeluruh dan utuh mengenai Efektivitas Media Pembelajaran Macromedia Flash dalam Pembelajaran Fiqih di Madrasah Ibtidaiyah Ainul Huda Juwet Ngronggot Nganjuk Secara aplikatif, dalam penelitian ini, peneliti berusaha memahami terlebih dahulu mengenai arti peristiwa dan kaitan-kaitannya dengan penggunaan media pembalajran macromedia dan berusaha masuk dalam dunia konseptual para subjek yang sedang diteliti sedemikian rupa, sehingga mudah dimengerti apa dan bagaimana suatu pengertian yang dikembangkan oleh

3 Sanapiah Faisal, Penelitian Kualitatif: mereka di sekitar peristiwa dalam kehidupan sehari-hari.

Peneliti menggunakan jenis penelitian studi kasus, yang mana penggunaan metode ini karena sebuah inquiry secara empiris yang menginvestigasi fenomena sementara dalam konteks kehidupan nyata (real life context), ketika batas antara fenomena dan konteks tidak tampak secara jelas; dan sumbersumber fakta ganda yang digunakan.

\section{Hasil dan Pembahasan}

\section{Macromedia Flash}

Macromedia Flash adalah program untuk membuat animasi dan aplikasi web profesional. Bukan hanya itu, Macromedia Flash juga banyak digunakan untuk membuat game, animasi kartun, dan aplikasi multimedia interaktif seperti demo produk dan tutorial interaktif. ${ }^{4}$ Software keluaran Macromedia ini merupakan program untuk mendesain grafis animasi yangsangat populer dan banyak digunakan desainer grafis. Kelebihan flash terletak pada kemampuannya menghasilkan animasi gerak dan suara. Awal perkembangan flash banyak digunakan untuk animasi pada website, namun saat ini mulai banyak digunakan untuk media pembelajaran karena kelebihankelebihan yang dimiliki.

Macromedia Flash merupakan gabungan konsep pembelajaran dengan teknologi audiovisual yang mampu

${ }^{4}$ Chandra, (2009), 7 Jam Belajar Flash MX 2004 untuk Orang Awam, Maxikom, Palembang.h. 2. 
menghasilkan fitur-fitur baru yang dapat dimanfaatkan dalam pendidikan. Pembelajaran berbasis multimedia tentu dapat menyajikan materi pelajaran yang lebih menarik, tidak monoton, dan memudahkan penyampaian. Peserta didik dapat mempelajari materi pelajaran tertentu secara mandiri dengan komputer yang dilengkapi program multimedia. ${ }^{5}$

Program Macromedia Flash terdiri dari beberapa versi, versi terbaru adalah Flash 8. Flash versi sebelumnya antara lain: Flash 5, Flash MX, dan Flash MX 2004. Semakin baru versi program, maka semakin lengkap fasilitas yang diberikan. ${ }^{6}$

Macromedia Flash memiliki sejumlah kelebihan. Beberapa kelebihan Flash antara lain:

1. Animasi dan gambar konsisten dan fleksibel, karena tetap terlihat bagus pada ukuran jendela dan resolusi layar berapapun pada monitor pengguna.

2. Kualitas gambar terjaga. Hal ini disebabkan karena flash menggunakan teknologi Vector Graphics yang mendeskripsikan gambar memakai garis dan kurva, sehingga ukurannya dapat diubah sesuai dengan kebutuhan tanpa mengurangi atau mempengaruhi kualitas gambar. Berbeda dengan gambar bitmap seperti bmp, jpg dan gif yang gambarnya pecah-pecah ketika ukurannya dibesarkan atau diubah

5 Chusnul Chotimah, Macromedia Flash Sebagai Media Pembelajaran http://www.smunet.com/main.php?act=int\&xkd=169_diakses tanggal 1 Juni 2019 karena dibuat dari kumpulan titiktitik.

3. Waktu loading (kecepatan gambar dan animasi muncul atau loading time) lebih cepat dibandingkan dengan pengolah animasi lainnya seperti animated gif dan java Applet.

4. Mampu membuat website interaktif, karena pengguna (user) dapat menggunakan keyboard atau mouse untuk berpindah ke bagian lain dari halaman web atau movie, memindahkan obyek, memasukkan informasi ke form.

5. Mampu menganimasi grafis yang rumit dengan sangat cepat, sehingga membuat animasi layar penuh bisa langsung disambungkan ke situs web.

6. Mampu secara otomatis mengerjakan sejumlah frame antara awal dan akhir sebuah urutan animasi, sehingga tidak membutuhkan waktu yang lama untuk membuat berbagai animasi.

7. Mudah diintegrasikan dengan program macromedia yang lain, seperti Dreamweaver, Fireworks, dan Authorware, karena tampilan dan tool yang digunakan hampir sama.

8. Dapat diintegrasikan dengan skrip sisiserver (server side scripting) seperti CGI, ASP dan PHP untuk membuat aplikasi pangkalan data web.

9. Lingkup pemanfaatan luas. Selain tersebut diatas, dapat juga dipakai untuk membuat film pendek atau

${ }^{6}$ Edy Wihardjo, Pembelajaran Berbantuan Komputer, http : / / elearning. unei. ac. id/ courses/ CL4fe8/document/buku ajar PBKom.pdf? idReq=CL02d1. diakses tanggal 1 Juni 2019 
kartun, presentasi, iklan atau web banner, animasi logo, kontrol navigasi dan lain-lain. ${ }^{7}$

Macromedia Flash dapat pula dimanfaatkan sebagai sarana dalam melakukan simulasi untuk melatih keterampilan dan kompetensi tertentu. Misalnya, penggunaan simulator kokpit peserta didik dalam akademi penerbangan dapat berlatih tanpa menghadapi risiko jatuh. Contoh lain dari penggunaan Macromedia flash adalah tampilan multimedia dalam bentuk animasi yang memungkinkan mahasiswa pada jurusan eksakta, biologi, kimia, dan fisika melakukan percobaan tanpa harus berada di laboratorium. ${ }^{8}$

Perkembangan teknologi komputer saat ini telah membentuk suatu jaringan (network) yang dapat memberi kemungkinan bagi siswa untuk berinteraksi dengan sumber belajar secara luas. Jaringan komputer berupa internet dan web telah membuka akses bagi setiap orang untuk memperoleh informasi dan ilmu pengetahuan terkini dalam bidang akademik tertentu. Diskusi dan interaksi keilmuan dapat terselenggara melalui tersedianya fasilitas internet dan web di sekolah.

Penggunaan Macro media flash tidak hanya dapat memberikan kontribusi yang positif terhadap kegiatan akademik siswa tapi juga bagi guru. pesawat terbang yang memungkinkan

Internet dan web dapat memberi kemungkinan bagi guru untuk menggali informasi dan ilmu pengetahuan dalam mata pelajaran yang menjadi bidang ampuannya. Melalui penggunaan Macro media flash, guru akan selalu siap mengajarkan ilmu pengetahuan yang mutakhir kepada siswa. Hal ini tentu saja menuntut kemampuan guru itu sendiri untuk selalu giat memakai Macro media flash dalam bidang yang menjadi keahliannya.

Media dalam pembelajaran memiliki fungsi sebagai alat bantu untuk memperjelas pesan yang disampaikan guru. Media juga berfungsi untuk pembelajaran individual dimana kedudukan media sepenuhnya melayani kebutuhan belajar siswa (pola bermedia).

\section{Pemanfaatan Macromedia Flash Sebagai} Media Pembelajaran Fiqih

Macromedia flash adalah salah satu Future Splash animator yang memudahkan pembuatan animasi pada layar komputer dalam menampilkan gambar secara visual dan lebih menarik. Flash adalah salah satu software yang merupakan produk unggulan pembuat animasi gambar vektor, sehingga sangat membantu guru dalam membuat instrumen pembelajaran.

Macromedia flash adalah program untuk membuat animasi dan aplikasi web profesional. Bukan hanya itu,

${ }^{7}$ Edy Wihardjo, Pembelajaran Berbantuan Komputer, http : / / elearning. unei. ac. id/ courses/CL4fe8/document/buku ajar PBKom.pdf? idReq=CL02d1. diakses tanggal 1 Juni 2019, $\begin{array}{ccr}8 & \text { Http://wordpress.com } & \text { Media } \\ \text { pembelajaran } & \text { berbasis }\end{array}$

Media Pembelajaran Berbasis Komputer AKHMAD SUDRAJAT TENTANG PENDIDIKAN.htm, diakses tanggal 20 Juni 2019 
Macromedia Flash juga banyak digunakan untuk membuat game, animasi kartun, dan aplikasi multimedia interaktif seperti demo produk dan tutorial interaktif. ${ }^{9}$

Cara kerja macromedia flash ini berupa penyajian animasi secara visual dalam bentuk tulisan, gambar dan lainlain yang dapat digerakkan sesuai yang diinginkan berdasarkan konsep yang dipakai. Melalui penerapan model pembelajaran ini diharapkan akan mempermudah siswa dalam mengungkapkan bagaimana ia melihat persoalan dan apa yang akan dibuat persoalan itu. Inilah salah satu jalan menciptakan refleksi yang menutut kesadaran akan apa yang sedang dipikirkan dan dilakukan.

Proses pembelajaran fiqih di MI Ainul Huda Juwet Ngronggot Nganjuk berdasarkan hakekat keilmuan fiqih mempunyai karakteristik yang khas. Pembelajaran dimulai dengan adanya contoh orang yang melakukan ibadah haji sehingga menghasilkan masalah yang berkaitan dengan percobaaan yang dilakukan. Artinya, siswa diajak langsung atau bersinggungan langsung dengan masalah-masalah yang terjadi. Dengan begitu, kedewasaan mendeteksi masalah secara otomatis akan terasah.

Masalah-masalah yang muncul dibawa ke dalam kelas untuk selanjutnya dilakukan diskusi kelompok dan diskusi kelas. Unjuk kebolehan siswa di depan kelas dilaksanakan agar kesalahan konsep yang dimungkinkan terjadi masih bisa diperbaiki. Dengan demikian kemandirian siswa dengan sendirinya akan terbentuk melalui proses pemahaman secara kongkrit dan mencari jawaban atas pertanyaan-pertanyaan yang muncul dilaksanakan agar kesalahan konsep yang dimungkinkan terjadi masih bisa diperbaiki. Dengan demikian kemandirian siswa dengan sendirinya akan terbentuk melalui proses penemuan fakta dan mencari jawaban atas pertanyaan-pertanyaan yang muncul.

Macromedia Flash merupakan gabungan konsep pembelajaran dengan teknologi audiovisual yang mampu menghasilkan fitur-fitur baru yang dapat dimanfaatkan dalam pendidikan. Pembelajaran berbasis multimedia tentu dapat menyajikan materi pelajaran yang lebih menarik, tidak monoton, dan memudahkan penyampaian. Peserta didik dapat mempelajari materi pelajaran tertentu secara mandiri dengan komputer yang dilengkapi program multimedia. ${ }^{10}$

Untuk memanfaatkan media pembelajaran berbantuan media macromedia flash, diperlukan program dengan tampilan menarik sedemikian asik yang dapat menambah minat siswa untuk belajar fiqih dengan tepat dan menyenangkan. Oleh karena itu, guru fiqih memlih media media macromedia flash

net.com/main.php?act $=$ int\&xkd=169 diakses tanggal 1 Agustus 2019 
untuk dimanfaatkan menjadi media pembelajaran pada materi fiqih di $\mathrm{MI}$ Ainul Huda Juwet Nganjuk

Peneliti berpendapat bahwa alasan guru fiqih dalam memilih pembelajaran macromedia flash karena program ini adalah program yang biasa digunakan untuk membuat aplikasi untuk administratif perkantoran yang kemudian dimungkinkan untuk dikembangkan menjadi aplikasi pembelajaran. Adapun perangkat yang akan. dikembangkan untuk menunjang 3 . pengembangan media pembelajaran macromedia flash ini adalah Rencana Pelaksanaan Pembelajaran (RPP). Artinya, seberapa canggih alat pembelajaran, dalam penggunaannya harus disesuaikan dengan aturan yang dibuat oleh guru.

Macromedia Flash merupakan software yang dirancang untuk membuat animasi berbasis vektor dengan hasil yang mempunyai ukuran yang kecil. Awalnya software ini memang diarahkan untuk membuat animasi atau aplikasi berbasis internet (online). Tetapi paday. perkembangannya banyak digunakan untuk membuat animasi atau aplikasj. yang bukan berbasis internet (offline). Dengan Actionscript 2.0 yang dibawanya, Flash dapat digunakan untuk mengembangkan game atau bahan ajar seperti kuis atau simulasi

Pemanfaatan Macromedia Flash untuk animasi atau pembuatan bahan ajar interaktif tidaklah sulit, tool-tool yang tersedia cukup mudah digunakan, beberapa template dan component juga sudah disediakan siap digunakan. Dengan anggapan sotfware flash telah terinstal pada komputer yang Anda gunakan, berikut ini langkah awal untuk mengenal penggunaan flash. Untuk membuka program Macromedia Flash Anda dapat melakukan cara berikut:

Pilih Start > Program > Macromedia > Flash 8

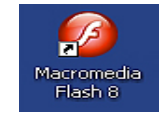

Atau Pilih Ikon Flash 8 pada dekstop (Layar monitor) Beberapa saat akan muncul jendela dialog seperti berikut.

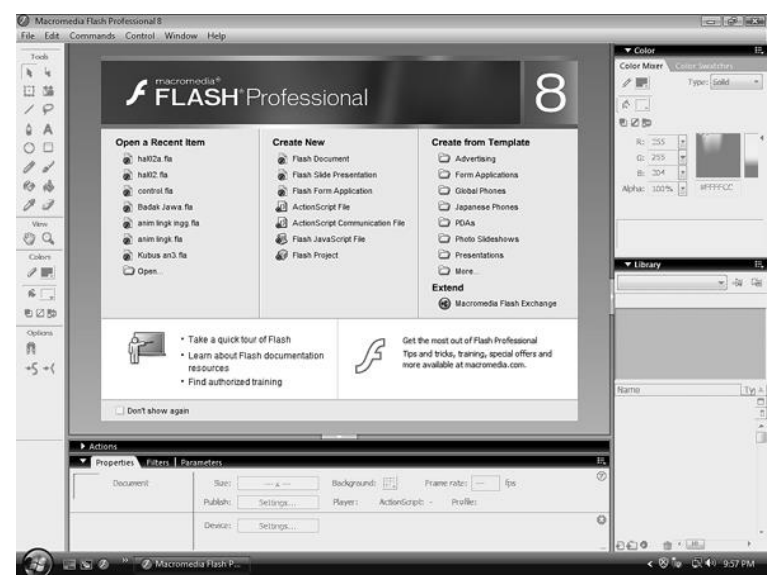

Pilih Create New > Flash Document untuk memulai membuat file baru. Pilih Open a Recent New > Open untuk membuka file flash.

Setelah terbuka makan akan muncul tambilan seperti di bawah ini:

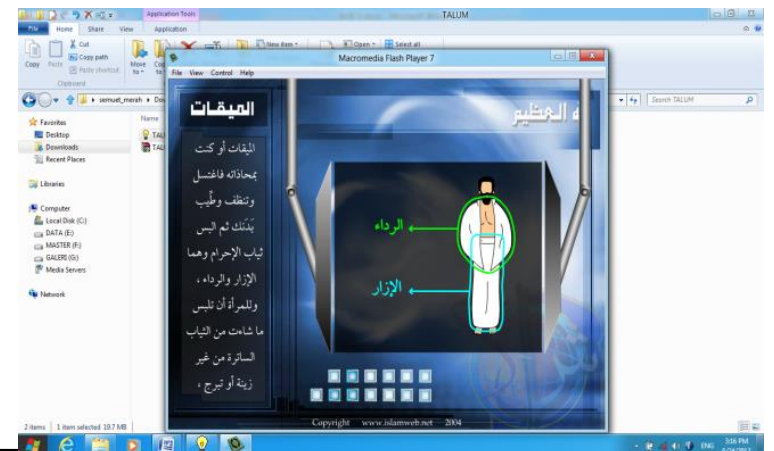


Gambar: Macromedia Flas Persiapan Ihram

Animasi yang terlihat $\mathrm{di}$ atas termasuk animasi frame to frame. Animasi ini adalah jenis animasi yang paling banyak memakan kapasitas file dan memori, karena itu lebih baik penggunaan animasi ini hendaknya diminimalis. Animasi frame per frame menuntut banyak gambar yang harus dibuat. Efek animasi diciptakan dengan mengganti gambar yang satu dengan gambar yang lain selama beberapa waktu. Semua gambar yang bergerak dihasilkan dari gambar yang berbedabeda tiap framenya. Karena animasi frame per frame harus memiliki gambar yang unik tiap framenya maka animasi frame per frame sangat ideal untuk membuat animasi yang kompleks yang terdiri dari banyak perubahan seperti ekspresi wajah. ${ }^{11}$

Setelah program macromedia flash terbuka dan siap untuk digunakan guru fiqih akan menentukan seberapa baik penampakan perangkat ajar berbasis teknologi informasi dengan menggunakannya sendiri dan meminta orang yang berpengalaman desain yang berhasil. Prosedur ini disebut tinjauan ulang perangkat ajar berbasis teknologi informasi. Peneliti akan menilai seberapa baik perangkat ajar berbasis teknologi informasi bekerja dengan pedoman mengamati hasil dari siswa yang mempelajari dan menaksir berapa banyak mereka belajar. Siswa ini harus mewakili pada siapa materi pembelajaran dimaksudkan. Tahap ini meliputi pengujian dan pengesahan (validasi).

\section{Efektifitas Penggunaan Macromedia Flash}

Efektifitas menunjukan taraf tercapainya suatu tujuan, suatu usaha dikatakan efektif jika usaha itu mencapai tujuannya. Efektifitas pembelajaran tidak terlepas dari figur seorang guru dengan peranannya sebagai seorang fasilitator dan motivator. Untuk itu guru perlu mempertimbangkan segi kemampuan setiap siswa dan strategi pengajaran, keduanya dirancang secara sistematis, bersifat konseptual tetapi praktis, realitas dan fleksibel terhadap masalah interaksi pengajaran. Dengan demikian pembelajaran dikatakan berlangsung secara efektif sehingga proses pembelajaran yang dilaksanakan membuahkan hasil pencapaian tujuan instruksional secara lebih tepat dan optimal dengan waktu pengajaran yang sudah ditentukan sesuai dengan bobot materi pelajaran maupun pencapaian tujuan, maka diharapkan dapat memberikan keberhasilan bagi siswa. Di dalam proses belajar mengajar banyak faktor yang mempengaruhi terhadap berhasil tidaknya sebuah pembelajaran, antara lain kurikulum, metode pembelajaran, daya serap, presensi guru, presensi siswa dan prestasi belajar. 
Hal tersebut seperti yang dikatakan Azhar Arsyad ada beberapa manfaat praktis dari penggunaan media pembelajaran di dalam proses belajar mengajar sebagai berikut:

1. Media pembelajaran dapat memperjelas penyajian pesan dan informasi sehingga dapat memperlancar dan meningkatkan proses dan hasil belajar.

2. Media pembelajaran dapat meningkatkan dan mengarahkan perhatian anak sehingga dapat menimbulkan motivasi belajar, interaksi yang lebih langsung antara siswa dan lingkungannya, dan kemungkinan siswa untuk belajar sendiri-sendiri sesuai dengan kemampuan dan minatnya.

3. Media pembelajaran dapat mengatasi keterbatasan indera, ruang, dan waktu:

a. Obyek atau benda yang terlalu besar untuk ditampilkan langsung di ruang kelas dapat diganti dengan gambar, foto, slide, realita, film, radio, atau model.

b. Obyek atau benda yang terlalu kecil yang tidak tampak oleh indera dapat disajikan dengan bantuan mikroskop, film, slide, atau gambar.

c. Kejadian langka yang terjadi di masa lalu atau terjadi sekali dalam puluhan tahun dapat ditampilkan melalui rekaman video, film, foto, slide disamping secara verbal. d. Obyek atau proses yang amat rumit seperti peredaran darah dapat ditampilkan secara kongkret melalui film, gambar, slide, atau simulasi komputer.

e. Kejadian atau percobaan yang dapat membahayakan dapat disimulasikan dengan media seperti komputer, film, dan video.

f. Peristiwa alam seperti terjadinya letusan gunung berapi atau proses yang dalam kenyataan memakan waktu lama seperti proses kepompong menjadi kupu-kupu dapat disajikan dengan teknikteknik rekaman time-lapse untuk film, video, slide, atau simulasi komputer.

g. Media pembelajaran dapat memberikan kesamaan pengalaman kepada siswa tentang peristiwa-peristiwa di lingkungan mereka, serta memungkinkan terjadinya interaksi langsung dengan guru, masyarakat, dan lingkungannya misalnya melalui karyawisata, kunjungankunjungan ke museum atau kebun binatang. ${ }^{12}$

Media pembelajaran fiqih memanfaatkan macromedia flash di MI Ainul Huda Juwet Ngronggot Nganjuk tergolong dalam jenis media pembelajaran audio visual aid karena mampu menampilkan suara, gambar dan gerakan secara bersama-sama. Hal ini sangat membantu peserta didik dalam memahami materi haji daripada 
menggunakan sistem ceramah biasa maupun menggunakan media gambar dan diagram. Media ini juga lebih efektif karena peserta didik akan mendapatkan pengalaman lebih jelas dan konkrit tentang pelaksanaan haji dan rukunrukunnya, dan juga lebih efisien karena peserta didik akan memiliki kompetensi yang diharapkan dalam waktu singkat.

Macromedia flash dapat pula dimanfaatkan sebagai sarana dalam melakukan simulasi untuk melatih keterampilan dan kompetensi tertentu. Misalnya, penggunaan simulator kokpit pesawat terbang yang memungkinkan peserta didik dalam akademi penerbangan dapat berlatih tanpa menghadapi risiko jatuh. Contoh lain dari penggunaan Macro media flash adalah tampilan multimedia dalam bentuk animasi yang memungkinkan mahasiswa pada jurusan eksakta, biologi, kimia, dan fisika melakukan percobaan tanpa harus berada di laboratorium.

Penggunaan macromedia flash tidak hanya dapat memberikan kontribusi yang positif terhadap kegiatan akademik siswa tapi juga bagi guru. Internet dan web dapat memberi kemungkinan bagi guru untuk menggali informasi dan ilmu pengetahuan dalam mata pelajaran yang menjadi bidang ampuannya. Melalui penggunaan Macro media flash, guru akan selalu siap mengajarkan ilmu pengetahuan yang mutakhir kepada siswa. Hal ini tentu saja menuntut kemampuan guru itu sendiri untuk selalu giat memakai Macro media flash dalam bidang yang menjadi keahliannya.
Media pembelajaran dengan memakai macromedia flash ini sangat efektif dalam proses belajar mengajar fiqih bab haji, karena dapat membantu daya pikir anak yang tentu dalam menerangkan bab haji tidak mungkin bisa mengajak meraka kesana melihat pelaksanaan ibadah haji. Dengan adanya media ini kita seakan-akan bisa mengikuti kegiatan pelaksanaan ibadah haji di Mekkah. Sudah bagus karena lebih baik daripada memakai media ceramah biasa, apalagi memakai gambar atau diagram saja.

Media ini lebih efektif dan efisien, efektif karena siswa dapat mempunyai pengalaman yang jelas dan konkrit tentang pelaksanaan ibadah haji. Efisien karena dalam waktu singkat anak lebih memiliki kompetensi setelah melihat gerakan-gerakan haji melalui media ini.

Salah satu tujuan media pembelajaran adalah agar materi dapat disampaikan dengan jelas dan sekonkrit mungkin, sesuai dengan tujuan tersebut media ini bisa menampilkan materi secara lebih jelas dan konkrit. Akan tetapi suara media masih kurang jelas dan gambarnya masih kabur. Juga belum ada gambar video tentang mabid di Muzdalifah.

Dalam pemilihan media harus sesuai dengan kriteria pemilihan media yang baik yaitu mendukung materi, sesuai dengan tujuan pembelajaran, tidak membosankan, efektif dan efisien.

Adapun Kelebihan media elektronika adalah: 
1. Memiliki kemampuan menangkap, menyimpan, dan dapat ditayangkan sewaktu-waktu (Fixative Property)

2. Dapat digunakan sesuai dengan kebutuhan; dapat dipercepat atau diperlambat, diperbesar atau diperkecil, dan dapat digunakan sekarang atau nanti (Manipulative Property)

3. Sekali tayang dapat dinikmati oleh seluruh pengguna (Distributive Property $)^{13}$

Agar lebih efektif media ini harus didukung dengan perangkat media yang lainnya ketika disampaikan di kelas, yaitu dengan memakai LCD proyektor kecuali telah tersedia komputer bagi masing-masing siswa. Jadi, media ini akan menjadi kurang fungsional kalau tidak bisa dinikmati oleh seluruh siswa.

Melihat kualitas tampilan gambar media ini sudah sangat bisa membantu proses pembelajaran. Akan tetapi, masalah tampilan tidak perlu terlalu njlimet agar tidak mengaburkan tujuan menggunakan media ini yaitu agar ssiwa dapat memahami materi fiqih bab haji.

Efektifitas media pembelajaran di atas juga sesuai dengan pendapat Basyiruddin Usman yang menyatakan bahwa manfaat media pembelajaran antara lain:

1. Media dapat mengatasi berbagai keterbatasan pengalaman yang dimiliki siswa atau mahasiswa.

2. Media dapat mengatasi ruang kelas. 
pembelajaran bisa terus dikembangkan dan dimanfaatkan secara efektif.

Setelah melakukan observasi langsung di MI Ainul Huda dan melakukan diskusi dengan guru mata pelajaran fiqih, peneliti memperoleh beberapa informasi, diantaranya pemanfaatan macromedia flash sebagai media pembelajaran sudah cukup efektif. Berdasarkan kajian terhadap karakteristik mata pelajaran fiqih di tingkat madrasah ibtidaiyah dan telaah terhadap teoriteori belajar, maka peneliti memilih untuk membuat media pembelajaran agar menumbuhkan minat siswa terhadap pelajaran fiqih. Media yang dipilih oleh guru fiqih adalah media pembelajaran macromedia flash merupakan pilihan yang tepat. Ketertarikan anak didik usia madrasah ibtidaiyah yang sangat tinggi pada teknologi, khususnya komputer berbasis animasi adalah salah satu alasan peneliti memilih media ini. Di samping itu komputer berbasis animasi adalah sarana yang mau tidak mau harus dikuasai oleh siswa untuk masa depan biar tidak ketinggalan informasi.

Macromedia merupakan perangkat lunak (software) yang dimanfaatkan pengembangannya dari kelebihan yang dimiliki oleh multimedia. Dimanipulasi secara digital. Macromedia flash merupakan aplikasi yang digunakan untuk melakukan desain dan membangun perangkat presentasi, publikasi, atau aplikasi lainnya yang membutuhkan ketersediaan sarana interaksi dengan penggunaan proyek yang dibangun dengan flash, bisa terdiri atas teks, gambar, animasi sederhana, video, atau efek-efek lainnya.7 Flash dikembangkan sejak tahun 1996 yang pada awalnya aplikasinya hanya berupa program animasi sederhana GIF Animation. Namun sekarang ini sudah berkembang demikian pesatnya menjadi aplikasi raksasa yang digunakan oleh hampir semua orang yang menekuni bidang desain dan animasi berbasis komputer.

Jadi media pembelajaran berbantuan komputer secara tidak langsung juga dapat melatihkan ketrampilan siswa dalam menggunakan media macromedia flash. Dengan materi ajar ibadah haji, siswa dapat memperoleh materi pelajaran serta tampilan soal soal yang dikemas secara menarik di media pembelajaran macromedia flash berbasis, sehingga siswa dapat mengikuti pelajaran fiqih dengan minat yang cukup tinggi. Dan dengan minat yang cukup tinggi itu diharapkan siswa dapat memperoleh hasil belajar yang maksimal.

\section{Kesimpulan}

1. Pemanfaatan macromedia flash sebagai media pembelajaran fiqih di Kelas $\mathrm{V}$ Madrasah Ibtidaiyah Ainul Huda Juwet Ngronggot Nganjuk berdasarkan model Alessi dan Trollip yaitu secara garis besar di bagi menjadi beberapa tahapan pemakaian antara lain: menentukan kebutuhan dan tujuan, mengumpulkan sumber, mempelajari materi, menghasilkan gagasan, mendesain pembelajaran, 
membuat materi yang mendukung, mengevaluasi dan meninjau kembali.

2. Efektifitas penggunaan macromedia flash pada pembelajaran fiqih di Kelas V Madrasah Ibtidaiyah Ainul Huda Juwet Ngronggot Nganjuk cukup efektif untuk menunjang pembelajaran di madrasah karena didukung kualitas tampilan yang sangat bagus dan mudah diterima oleh ssiwa, penyajian materi jelas dan menampilkan hal-hal yang kongkrit sehingga siswa mudah memahami materi, interaksi pengguna dan interaksi program yang baik sehingga guru dan siswa bisa aktif dalam belajar.

\section{Daftar Pustaka}

Arifin, Zaenal. "Penulisan Karya Ilmiah dalam Jurnal Nasional". Makalah disajikan dalam Lokakarya Penelitian Tingkat Dasar bagi Dosen IAIT Kediri, P3M IAIT Kediri. Kediri, 12 Juli 2016

Chandra, (2008), 7 Jam Belajar Flash MX 2004 untuk Orang Awam Maxikom, Palembang..

Chusnul Chotimah, Macromedia Flash Sebagai Media Pembelajaran http://www.smunet.com/main.ph p?act $=$ int\&xkd=169 diakses tanggal 1 Juni 2019

Djamarah, Syaiful Bahri dan Aswan Zain. Strategi Belajar Mengajar. Jakarta: Rineka Cipta, 2013.

http://www.smunet.com/main.php?act =int\&xkd=169, Chusnul Chotimah,
Macromedia Flash Sebagai Media

Pembelajaran. Diakses 24 Maret 2019

Edy Wihardjo, Pembelajaran Berbantuan Komputer, http : / / elearning. unei. ac. id/ courses/

CL4fe8/document/buku ajar PBKom.pdf? idReq=CL02d1. diakses tanggal 1 Juni 2019

Http://wordpress.com Media pembelajaran berbasis IT/ Media Pembelajaran Berbasis Ko mputer _ AKHMAD SUDRAJAT TENTANG PENDIDIKAN.htm, diakses tanggal 20 Juni 2019

Sanapiah Faisal, (1990), Penelitian Kualitatif: Dasar-Dasar dan Aplikasi, Malang: YA3.

Winkel, WS. Psikologi Pengajaran. Yogyakarta: Media Abadi, 2012.

Sanjaya, Wina. Strategi Pembelajaran Berorientasi Standar Proses Pendidikan. Jakarta: Kencana Prenada Media Group, 2013. 